\title{
S13. Forensic psychiatry
}

\section{QUALITY CRITERIA IN PSYCHIATRIC EXPERTISE}

P. Winckler, K. Foerster

Psychiatrische Universităts-Klinik, Sektion Forensische Psychiatrie, Osianderstr.22, D-72076 Tübingen

Aspects of quality control are of significant importance in the field of psychiatric expertise. In our department of forensic psychiatry we have worked out criteria in order to establish quality standards in psychiatric expertise.

Formal quality criteria refer to organization, duration and extent of psychiatric exploration. Diagnosis should be made according to DSM-III-A or ICD-10 criteria. Estimation of individual degree of disability is necessary.

Patients with neurotic or personality disorder require particular experience. Psychodynamic aspects of expert-patient-interaction must receive special attention.

Limits of psychiatric expertise must be outlined.
PRISONERS ON REMAND: PREVALENCE AND INCIDENCE OF MENTAL DISORDERS IN A RANDOM SAMPLE WITH SPECIAL REGARD TO SOLITARY CONFINEMENT.

\section{HS Andersen*, D Sestoft, T Lillebæk}

* Department of Psychiatry, Bispebjerg Hospital, Bispebjerg Bakke 23, 2400 Copenhagen NV, Denmark.

Ministry of Justice, Clinic of Forensic Psychiatry, Blegdamsvej 6B, 2200 Copenhagen N, Denmark.

A random sample of 228 Danish prisoners on remand in the largest custodial prison in Denmark, the Western Prison, were studied in a prospective, follow up design. 133 prisoners were imprisoned in solitary confinement (SC) and 95 in non-solitary confinement (non-SC). All were interviewed at reception by a psychiatrist with standardized qualitative and quantitative interviews (e.g. PSE-10, HDS, HAS, PCL$\mathrm{R}$ and GAS). For the rest of the imprisonment on remand the prisoners were interviewed after 3 weeks, after 2 months and thereafter every month. About $50 \%$ were interviewed at least twice and $20 \%$ at least 3 times.

In $28 \%$ of prisoners in SC and in $15 \%$ in non-SC a psychiatric disorder emerged during the imprisonment. Most emerging disorders were adjustment disorders and depressive disorders. Analysed with repeated measurement on quantitative measures of mental health the non-SC group had a significantly improved mental health status during imprisonment. The SC group was unchanged on a lower level than preprison. After transferral from SC to non-SC there was a significant improvement on measures of mental health. Potential confounding factors are less influential than the sort of imprisonment (i.e. SC vs. non-SC).

$\mathrm{SC}$ in prisoners on remand thus acts as a moderate health hazard compared with prisoners in non-SC. 
MONOAMINE OXIDASE ANI LATE CRIMINALITY IN FORMER JUVENILE DELINQUENTS.

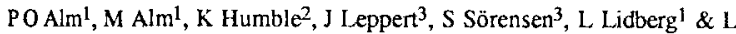
Oreland $d^{4}$.

1 Department of Clinical Neuroscience and Family Medicine, Section for Social and Forensic Psychiatry, Karolinska Institute, Box 4044, S-141 04 Huddinge, Sweden.

2 National Council for Crime Prevention, Atlasmuren 1, S-113 21 Stockholm

3 Department of Research, University of Uppsala, Central Hospital, S-721 89 Västerd's

4 Department of Medical Pharmacology, Box 593, University of Uppsala, S-751 24 Uppsala

Platelet monoamine oxidase (MAO) activity was estimated in 70 former juvenile delinquents and 40 controls, now aged 38 46 y. It was compared with their "early" criminal behaviour (before the age of 15 years) and their "late" registered criminality (from the age of 15 years). Mean platelet MAO activity in subjects with both "early" and "late" criminality was significantly lower than that in former delinquents without "late" criminality ( $p<0.001$ ). There was no significant difference in mean platelet MAO-activity between controls and delinquents with "early" but no "late" criminality. Delinquents with "early" criminality were divided into a low and a high MAO-group, according to the median platelet MAO activity of the controls without any registered criminality. The relative risk to be registered for "late" criminality was about 3.1 times higher for the subjects in the low MAO-group. Apparently, juvenile delinquents with low platelet MAO activity run an increased risk for continued criminal behaviour.

\section{LES ETATS DE STRESS POST-TRAUMATIQUES CHEZ LES VICTIMES DE VIOL}

M Darves-Bomoz, C Berger, A Degiovanni, Jl' Lépine, IH Soutoul, MT Grateau, I' Gaillard

Clinique Psychiatrique Universitaire, CHU de TOURS, 12 rue du Coq. 37541 - Saint Cyr sur Loire, France.

Le viol est une cause fréquente de traumatisme psychique. L'étude que nous présentons se propose d'étudier de manière prospective certains symptômes psychopathologiques positiraumatiques chez les victimes de viol.

L'étude concerne 35 victimes de viol qui ont consulté consécutivement dans le centre d'accueil des victimes de violences sexuelles de Tours. Les sujets ont eu des entretiens avec un psychiatre, fondés sur un ensemble d'instruments cliniques pour l'ćvaluation des troubles mentaux, notamment le SI-PTSD (Structured Interview for Post-Traumatic Stress Disorder). I.es entretiens ont été répétés sur une période de 6 mois après l'arrivée au centre (à l'arrivée, à 10 jours, à 1 mois, à 3 mois et à 6 mois).

La communication étudie la prévalence, lapparition et le profil évolutif du Stress Post-Traumatique dans cette population in cours de cette période de 6 mois.

Cette étude nous a conduit à mettre en avant la nécessité d'un traitement psychiatrique actif et precoce des victimes de violences sexuelles et la nécessité de dégager des moyens spécifiques à cet effet.
FORENSIC PSYCHIATRY IN RUSSIA: YESTERDAY, TODAY, TOMORROW T.B. Dmitrieva

Serbsky National Research Center for Social and Forensic Psychiatry, Kropotkinsky per. 23, 119839 Moscow, Russia

Forensic psychiatry, like the whole psychiatric system of Russia, was seriously deformed under totalitarian regime. In fact a system of psychiatric abuse developed, which was the result of the state socio-political system.

Now, in the period of construction of the legal state, the first Law on Psychiatric Care was adopted in Russia. New draft codes were prepared e.g.Criminal Code, Code of Criminal Procedure as well as a draft law on forensic evaluation. These drafts clarify the criteria of non-responsibility, introduce the concept of diminished responsibility, significantly strengthen the rights of the accused during forensic psychiatric evaluation, provide the possibility of evaluation procedure in non-state institutions and by private experts. The system of forensic-psychiatric institutions of Russia is being reviewed, including their staff standards and material basis. Juridical and organizational basis have been laid for special training in forensic psychiatry with certification and license provision.

Further development of democratic reforms in forensic psychiatry to a grate measure will depend on socio-political and economic situation in the country.

THE ROLE OF BROAD SCHIZOPHRENIA CONCEPT IN PSYCHIATRIC ABUSE: EVIDENCE FROM FORENSIC PSYCHIATRY CASES DM Gerulaitiene 1), A. Bunevicius 2)

1) Kaunas Red Cross Hospital, 2) Kaunas Medical Academy, Lithuania

The main factors responsible for the psychiatric abuse in Soviet Lithuania were in general two: repressive nature of psychiatric care and broad schizophrenia concept used in forensic psychiatry practice. Lithuanian psychiatry was oriented to Sneznevsky school of schizophrenia classification where a wide "umbrella" labelled schizophrenia over mental diseases made possible to locate under it many persons who were undesirable to the regime. Those psychotic diagnoses allowed isolate dissidents in special mental hospitals by Soviet law as unguilty due to "insanity". We presumed that the application of other psychiatric classification system would not allow to diagnose such persons as a psychotics or even having any psychiatric problems.

The aim of our study was to reevaluate case histories of dissidents, who were convicted for their views, according to ICD-10 classification and diagnostic criteria for research.

The results of present study suggest benefits of strictly standardized criteria of mental disorders for the use in forensic psychiatry. 